\title{
Determinants of Non-Performing Loans in Nigeria's Deposit Money Banks
}

\author{
EL-Maude, Jibreel Gambo \\ Department of Accountancy, MAUTECH Yola
}

\author{
Abdul-Rahman, Ahmad \\ Postgraduate Student of the Department of Accounting \\ Bayero University Kano \\ Ibrahim, Muhammad \\ Department of Accounting \\ Nuhu Bamalli Polytechnic Zaria, Kaduna State
}

\begin{abstract}
The study examines the relationship between bank specific and macroeconomic determinant of non-performing loans in Nigerian deposit money banks over the period of 5 years (2010 to 2014). A sample of 10 banks out of 15 quoted by the Nigerian Stock Exchange (NSE) was considered on a cross sectional basis. The study adopted non-survey research design and secondary data was used, generated from the bank's annual reports and accounts, Central Bank of Nigeria (CBN) and Nigerian Stock Exchange fact book respectively. The data were analysed using descriptive statistics, correlation coefficient and multiple regressions. As thus, Stata (version 12) was used as a statistical tool for data analysis. The findings reveal positive significant relationship between Non-Performing loans and Loan to deposit and Bank size; whereas relationship between capital adequacy ratio and Inflation reveals a positive insignificant relationship; whereas Return on asset had negative insignificant relationship with the rate of non-performing loans. Based on the findings, it is recommended that CBN for policy purposes should frequently assess the lending habit of deposit money banks in Nigeria. Finally, strengthening securities market will have a positive impact on the general improvement of the banking institutes' thereby increasing the effectiveness of the financial sector.
\end{abstract}

Keywords: Bank specific factors, Macroeconomic factors, Non-performing loans \& Deposit Money Banks.

\section{INTRODUCTION}

Banking business focuses largely on the acceptance of money in the form of deposits from members of the public (i.e. bank customers) and turning the deposits accessible to borrowers in the form of loans for investments, consumptions, and other purposes best known to the borrower. The loans may be in the forms of overdraft, loan and advances, business funding arrangements and local purchasing order financing, amid others. In consequence, lending is one the fundamental functions of Commercial Banks.

Loans symbolize investments and typically constitute the lengthened assets of banks. Individuals and organizations request for loans. The households seek loanable funds from 
banks when their excess of income over expenditure is negative (Mbat, 1995). Besides, individual business firms especially small scale enterprise request for loans from deposit money banks for working capital drives and re-investment. In granting loans to individuals, households, and/or business firms and other establishments, banks take into consideration factors such as liquidity risk, repayment method, and source of repayment and the purpose of such loans (Mbat, 1995).

Bank loans and advances are habitually short-term in nature. Mostly, in deposit money banks in Nigeria, the worth of loan portfolio rest on credit analysis carried out by the loan officer. The credit expert's role is to make sure that loans granted have a decent qualitative composition. The qualitative features of bank loans include high liquidity quotient, minimum risk and appropriate maturity structure. These qualitative elements are necessary to guarantee repayment on demand or maturity (Akpan, 2013). Though, in some instances, there may be default (i.e., the customer may fail to pay the interest and principal as they mature or as they fall due within the specified period as agreed between the lender (creditor) and borrower (debtor)). Once there is default and the debtor defaults as scheduled or retrieval is highly doubtful or it is probable to be protected, the loan turns out to be a non-performing loan which at last leads to bad debts.

Bad debt stems from either authorized facilities or unauthorized facilities given to customers. It is hard to remove bad debt entirely in the banking business, but it can be reduced to a manageable level. The risk assets such as total loans and advances form the key portion of the assets of a bank. The moment they are about to go bad, the well-being of the bank becomes negatively affected and that may be termed the sign of the end of the banks commercial activities. However, it is generally accepted that the proportion of non-performing loans is mostly associated with bank failures and financial crises in both developed and underdeveloped countries. In fact, profuse evidence depicts that the financial/banking crises in Nigeria were preceded by high level of non-performing loans.

One of the major causes of bank failure among other things in the Nigerian banking industry is the continuous deterioration of the quality of risk assets held by them (Akpan, 2013). The 2012 end of the year reports of Nigeria Deposit Insurance Corporation (NDIC) pointed out that in every \#1.00 loan granted by the Nigerian Deposit money banks, only 57/kobo was capable of being recovered. The injuries suffered as a result of losses prompted by bad debts have lessened the capital position of many of the banks. That is, their capital base has been worn by huge amount of non-performing loans. It is not refuting to endorse that high level of bad debts can cripple bank operations and survival. In sight of this, timely detection and management of non-performing loans cannot be underscored.

Consequent upon this, the paper seeks to examine the determinants of non-performing loans in Nigerian deposit money banks; specifically it addressed the objective: To examine the relationship between bank specific and macro-economic determinants and non-performing loans in Nigeria's deposits money banks. As such the rest of the paper is organize into four sections, starting from the conceptual frames and literature review as section two, where the relevant concepts on non-performing loans and lending as well as literatures were reviewed with a view to expose loopholes of the studied variables. Methodology form part of the third section, results and discussions as section four and finally conclusion and recommendations.

\section{CONCEPTUAL FRAMEWORK AND LITERATURE REVIEW}

This section presents the concept of Non-performing loans and review of related on determinants of Non-performing loans in Nigerian money deposits banks. 


\section{The Concept of Non-Performing Loans}

The concept of Non-performing loans differs from one country to another. A loan maybe considered non-performing in one country and might not be considered as such in another country. However, opinions in some cases do match. As such, the following is the definition suggested by the International Monetary Fund's (IMF) Compilation guide on financial soundness indicators (2015):

"A loan is non-performing when payments of interest and/or principal are past due by 90 days or more, or interest payments equal to 90 days or more have been capitalized, refinanced, or delayed by agreement, or payments are less than 90 days overdue, but there are other good reasons-such as a debtor filing for bankruptcy-to doubt that payments will be made in full."

According to Basel Committee on Banking Supervision (2001) as cited in Kargi (2011), loan is considered default when bank declares that a borrower (that is, debtor) cannot meet his/her obligation and repay the loan, or similarly to the first definition, the borrower past due more than 90 days on any payment of the bank credit. These definitions offer a sensible framework for identifying non-performing loans, which the repose of the report is based on.

In addition, the Nigerian banking regulation also defines NPL as follows: Nonperforming loan and advances are a loan whose credit quality has deteriorated and the full collection of principal and/or interest as per the contractual repayment terms of the loan and advances are in question (CBN, 2015).

By and large, NPLs are loans that are outstanding both in its principal and interest for a long period of time disagreeing to the terms and conditions under the loan contract as noted by (Gesu, 2014). Any loan facility that is not current in terms of repayment both on principal and interest conflicting to the terms of the loan agreement is NPLs. Thus, the amount of nonperforming loan measures the quality of bank assets (Tseganesh, 2012).

\section{Classification of Non-Performing Loans}

A loan is categorized as non-performing when the principal or interest is due and unpaid for six months or more from the first day of default (Prudential Financial Policy Department, 2014). However, 2010 CBN prudential guidelines for money deposit banks in section 15.1, classified non-performing loans facilities into three distinct categories as sub-standard, doubtful and lost on the basis of the following criteria.

On sub-standard facilities as defined by 15.1(e) subsection 1 of the 2010 prudential guidelines for money deposits banks considers unpaid principal and/or interest remain outstanding for more than 90 days but less than 180 days as objective criteria. Whereas such loan facilities which display well defined weaknesses which could affect the ability of borrowers to repay such as inadequate cash flow to service debt, under-capitalisation or insufficient working capital, absence of adequate financial information or collateral documentation, irregular payment of principal and/or interest, and inactive accounts where withdrawals exceed repayments or where repayments can hardly cover interest charges as subjective criteria.

Doubtful facilities are considered objective when unpaid principal and/or interest remain outstanding for at least 180 days but less than 360 days and are not secured by legal title to leased assets or perfected realisable collateral in the process of collection or realisation. It is subjective where in addition to the weaknesses associated with sub-standard credit facilities 
reflect that full repayment of the debt is not certain or that realisable collateral values will be insufficient to cover bank's exposure.

Loan lost facilities on the other hand were considered objective when unpaid principal and/or interest remain outstanding for 360 days or more and are not secured by legal title to leased assets or perfected realizable collateral in the course of collection or realization. However, facilities which in addition to the weaknesses associated with doubtful credit facilities, are considered uncollectible and are of such little value that continuation as a bankable asset is unrealistic such as facilities that have been abandoned, facilities secured with unmarketable and unrealizable securities and facilities extended to judgment debtors with no means or fore closable collateral to settle debts.

However, paragraph (f) of the 2010 prudential guidelines specify that, banks are required to adopt the criteria identified in paragraphs 15.1(e) to classify their loan portfolios in order to show the true accounting principles of their loans facilities. As such, licensed banks should note that the Central Bank of Nigeria reserves the right to object to the classification of any credit facility and to prescribe the classification it considers appropriate for such credit facility.

Provisions for Non-performing Loan other than "Specialized loans" as defined by the 2010 prudential guidelines for money deposits banks, licensed banks are mandated to make sufficient provisions for apparent losses based on the loan portfolio arrangement system set in paragraph 12.1 of CBN prudential guidelines (2014) in order to reveal their true financial condition. Two types of provisions (that is specific and general) are considered sufficient to achieve this objective. Specific provisions are made on the basis of apparent risk default on specific loan facilities while general provisions are made in respect of the fact that even performing loan facility harbours some risk of loss no matter how small. Thus, all licensed banks shall be mandated to make specific provisions for non-performing loan as identified below:

For facilities categorized as Sub-Standard, Doubtful, or Lost. According to CBN (2014:12):

"Interest unpaid for more than 90 days should be postponed and accepted on cash basis only and the principal to be refund that are unpaid by more than 90 days must be fully provided for and accepted on cash basis only."

For principal repayments not hither to due on non-performing loan facilities, provision should be made as follows: Sub-Standard Credit Facilities: 10\% of the outstanding balance; Doubtful Credit Facilities: 50\% of the outstanding balance; Lost Credit Facilities: 100\% of the outstanding balance. Provisioning and classifications specified in section 12.1 and 12.2 of CBN Prudential Guideline (2014) relate to commercial-money deposit banks, commodities financing, corporate loans, retail and consumer credits and facilities granted to federal, state and local governments and their parastatals. Other loans not specifically categorized as specialized loans are also subject to provisioning in section 12.1 and 12.2. Banks are, however mandated by the CBN prudential guidelines to disclose total loans unpaid in each specialized loan at the year end and made provision against such loans as possible. The banks shall also disclose non-performing loans by loan categories in the financial statements and the proportion and/or percentage to total loans along with measure of specific provision under each classification. 


\section{Concept of Bank Loans and Lending}

Money Deposits banks are depository institutions that are somewhat unrestricted in their ability to provide loans and that is why they are legalized mostly to issue checking accounts. Money deposit banks are the most important of all commercial depository institution (Leroy and Vanhoos, 2006) as cited in (Gesu, 2014). They create money through lending and purchasing securities (Thomas, 2006). Money deposit banks spread-out loans to diverse categories of borrowers for numerous dissimilar purposes.

One of the key functions of any money deposit bank is provision of loan to individuals, business people in the market, companies operating in various sectors of the economy and corporate bodies as mentioned earlier. As thus, Banks amass money from those individual who have excess and lend it to those in need for varied purposes. Consequently, banks' transitional function plays a vibrant role in the commercial activity. Banks accept customer deposits and use those funds to give loans to other customers or invest in other assets that will yield a return higher than the amount bank pays the depositor (Zewdu, 2010).

It however shows that customers' deposit is the major source of bank loan and therefore, amassed deposits have a direct positive effect on lending. Hence, bank credit is the main source of accessible debt financing for most customers while good loans are the most lucrative assets for banks. The major profit making goings-on in money deposit banks is generating loans to its customers. For that reason, similar to all other debt instruments, loan involves redistribution of financial assets eventually, among the lender and the borrower. The borrower at first receives a sum of money from the lender with the intention to refund, occasionally not in consistent portions, to the lender. This service is normally provided at a cost, well-known as interest on the debt. As one of the main obligations of financial institutions is to provide loans, it is usually the central source of income to banks. In addition, bank loans and credit also constitute one of the ways of increasing money supply in the economy (Felix and Claudine, 2008).

Loans are the major single source of income for banks. Bank loan embroils personal relationships concerning the bankers and borrowers when it goes well till the end. It has a highest possibility of default risk than other bank assets. Loans yield the higher rate of return among bank assets in compensation for lower liquidity and higher risk (Thomas, 2006). A loan composition greatly varies among banks based on their size, location, trade area and lending experts (MacDonald, 2006).

According to Zewdu (2010), lending is the provision of resources (granting loan) by one party to another. The second party doesn't reimburse the first party immediately there by generating a debt, and instead arranges either to repay or return those resources at a later date. Banks function as financial intermediaries, collecting funds from savers in the form of deposit and then supplying to borrowers as loans. Those functions benefit both the banks and the borrowers. Lending represents the heart of the industry and Loans are the dominant asset and represent 50-75 per cent to total amount at most banks, generate the largest share of operating income and represents the bank`s greatest risk exposure (MacDonald, 2006) as cited in (Nkurranah 2014).

\section{Factors Affecting Banks Loan}

According to Zewdu (2010), the sources of fund for lending are reserve, deposits and capital. All these sources may be affected by different factors and would have a direct influence on lending. Hence, lending is one of the main function of money deposit banks, the bank 
managements should pay more attention, to analyse and take all the necessary measures as soon as possible concerning both internal and external factors that may hinder/distress and/or limit the their bank lending process. Short of lending, may cause banks' incomes especially interest income highly weaken and affect bank continued existence. In this case, since nonperforming loans (NPLs) has a direct reflection of poor asset quality, the factors that influence banks loans have their own impact on NPLs (Rawlins et al. 2012).

According to Zewdu (2010), capital position, profitability, stability of deposits, economic conditions, influence of monetary and fiscal policies, ability and experience of bank personnel and credit needs of the area served has great influence on bank loans which might have impact on NPLs. These contravene the views of Black and Daniel (1989) as cited in Zewdu (2010) that interest rate, liquidity of fund and Tax rate affect bank lending and investing activities. These however goes in line with what Aleman (2012), has identified as factors affecting bank loans in his studies. These however corresponds to what Haneef et.al (2012) found to be the factors affecting bank loans. Besides, Ngoc, Trien and Diep (2014), were of the opinion that inflation, consumer price index, interest rate, exchange rate were factors affecting banks loans. Contrary to these views, Korankye (2014) opined that late disbursement of the loan, business failure, unfavourable payment terms, high interest rate, and inadequate loan sizes, unforeseen contingencies, for instance illness and death of a family member, lack of training for the clients before and after disbursement as the factors affecting loans. This however, shows that factors affecting bank loans depends on the country where one belongs to and as such these factors to some extend are positive in one country and negative to another.

\section{Five C's of Non-performing loans}

As noted by (MacDonald, 2006; and Gesu 2014), there are five C's considered as bad credits which represent the disputes used to guard against/avert bad loans. These are as follows:

Complacency: refers to propensity to which one assumes that things were good in the past, so they will be good in the future. For instance, Supposing the past loan settlement success since things have incessantly worked out previously.

Carelessness: indicates the poor endorsing typically showed by scant loan documentation, lack of up-to-date financial information or other relevant information in the credit records, and lack of protective arrangements in the loan agreement. Each of these makes it hard to monitor a borrower`s improvement and detect problems before they are uncontrollable.

Communication ineffectiveness: failure to visibly communicate the banks objectives and policies. This is when loan delinquency can arise. Therefore, the bank management need to clearly and effectively communicate and impose the loan policies and loan officers should make the management conscious of specific problems with existing loans as soon as they appear.

Contingencies: refers the lenders' tendency to play down/ignore circumstances in which a loan might be default. It focuses on trying to make a deal work rather than identifying down side risk.

Competition: involves following the competitors' action rather than monitoring the bank's own credit standards. Banks, however, still have required expertise, experiences, and customer focus to make them the preferred lender for many types of loan. Lending is not just a matter of making loan and waiting for repayment. Loan must be monitored and closely supervised to prevent loan losses (MacDonald, 2006). 


\section{Empirical Literature}

There are many evidences which identify key determinants of bank loans in relation to macroeconomic determinants on non-performing loans. Some selected studies were reviewed; many scholars have conducted a lot of studies on determinants non-performing loans, as a result of its impact on bank's failure. There are many variables that affect non-performing loans in deposit money banks. As such, the researcher focused on both bank specific and macroeconomic variables in determining NPLs of deposit money banks in Nigeria. However, multiple variables that got more attention are involved in this study, loan to deposit ratio, capital adequacy/solvency ratio, profitability (ROA \& ROE), lending rate, inflation and effective tax rate.

Louzis, Vouldis and Metaxas (2010) conducted a study to examine the determinants of NPLs in the Greek financial sector using fixed effect model from 2003-2009 periods. The variables included were ROA, ROE, solvency ratio, loan to deposit ratio, inefficiency, credit growth, lending rate and size, GDP growth rate, unemployment rate and lending rates. The finding reveals that loan to deposit ratio, solvency ratio and credit growth has no significant effect on NPLs. However, ROA and ROE has negative significant effect whereas inflation and lending rate has positive significant effect on NPLs. It justifies that performance and inefficiency measures may serve as proxies of management quality.

Djiogap and Ngomsi (2012) investigated the determinants of bank long-term loan in the Central African Economic and Monetary Community (CEMAC). They used the panel data of 35 commercial banks from six African countries over the period 2001-2010. They used fixed effect model to examine impact of bank size, GDP growth and capital adequacy ratio on NPLs. The study found negative significant impact of CAR on the level of NPLs. Their finding justifies as more diversified banks and well capitalized banks are better able to withstand potential credit. However, inflation variable is statistically insignificant in explaining the total business loans ratios of banks.

In the work of Saba, Kauser and Azeem (2012) where they examined "Determinants of Nonperforming Loan on US banking sector" also investigate the bank specific and macroeconomic variables of nonperforming loans from 1985 to 2010 period using OLS regression model. They considered total loans, lending rate and Real GDP per capital as independent variables. The finding reveals as real total loans have positive significant effect whereas interest rate and GDP per capital has negative significant association with NPLs. Similarly, Mileris (2012) on the title of "macroeconomic determinants of loan portfolio credit risk in banks" was used multiple and polynomial regression model with cluster analysis, logistic regression, and factor analysis for the prediction. The finding indicates that NPLs are highly dependent of macroeconomic factors.

However, Swamy (2012) conducted a study to examine the macroeconomic and indigenous determinants of NPLs in the Indian banking sector using panel data a period from 1997 to 2009. The variables included were GDP growth, inflation rate, per capital income, saving growth rate, bank size, loan to deposit ratio, bank lending rate, operating expense to total assets, ratio of priority sector`s loan to total loan and ROA. The study found that real GDP growth rate, inflation, capital adequacy, bank lending rate and saving growth rate had insignificant effect; whereas loan to deposit ratio and ROA has strong positive effect but bank size has strong negative effect on the level of NPLs. 
Beside, Farhan et al. (2012) on the title of "Economic Determinants of Non-Performing Loans: Perception of Pakistani Bankers" utilized both primary and secondary data in 2006 years. The data was collected from 201 bankers who are involved in the lending decisions or handling nonperforming loans portfolio. Correlation and regression analysis was carried out to analyse the impact of selected independent variables. The variables included were interest rate, energy crisis, unemployment, inflation, GDP growth, and exchange rate. The study found that, interest rate, energy crisis, unemployment, inflation and exchange rate has a significant positive relationship whereas GDP growth has insignificant negative relationship with the nonperforming loans.

Skarica (2013) also conducted a study on the determinants of NPLs in Central and Eastern European countries. In the study, Fixed Effect Model and seven Central and Eastern European countries for 2007-2012 periods was used. The study utilized loan growth, real GDP growth rate, market interest rate, Unemployment and inflation rate as determinants of NPLs. The finding reveals as GDP growth rate and unemployment rate has statistically significant negative association with NPLs with justification of rising recession and falling during expansions and growth has an impact on the levels of NPLs. This shows as economic developments have a strong impact on the financial stability. The finding also reveals as inflation has positive impact with justification as inflation might affect borrowers' debt servicing capacities.

In addition to this, Tomak (2013) conducted study on the "Determinants of Bank's Lending Behaviour of commercial banks in Turkish" for a sample of eighteen from 25 banks. The main objective of the study was to identify the determinants of bank`s lending behaviour. The data was covered 2003 to 2012 periods. The variables used were size, access to long term funds, interest rates, GDP growth rate and inflation rate. The finding reveals that bank size, access to long term loan and inflation rate have significant positive impact on the banks lending behaviour but, interest rates and GDP are insignificant.

Ali and Iva (2013) who conducted study on "the impact of bank specific factors on NPLs in Albanian banking system" considered Interest rate in total loan, credit growth, inflation rate, and exchange rate and GDP growth rate as determinant factors. They utilized OLS regression model for panel data from 2002 to 2012 period. The finding reveals a positive association of loan growth and real exchange rate, and negative association of GDP growth rate with NPLs. However, the association between interest rate and NPL is negative but week. And also inflation rate has insignificant effect on NPLs.

An Empirical Study made on Commercial Banks in Pakistan by Badar and Yasmin (2013) on the title of "Impact of Macroeconomic Forces on Nonperforming Loans" the long and short run dynamics between nonperforming loans and macroeconomic variables covering the period from 2002 -2011 of 36 commercial banks in Pakistan were assessed. In the study, inflation, exchange rate, interest rate, gross domestic product and money supply were included as macroeconomic variables. They applied vector error correction model. The study found that as there is strong negative long run relationships exist of inflation, exchange rate, interest rate, gross domestic product and money supply with NPls.

Ranjan and Chandra (2013) analysed the determinants of NPLs of commercial banks' in Indian in 2002 the study utilized panel regression model and found that lending rate also have positive impact on the NPLs justifying that the expectation of higher interest rate induced the changes in cost conditions to fuel and further increase in NPLs. Besides, loan to deposit ratio had negative significant effect on NPLs justifying that relatively more customer friendly bank is 
most likely face lower defaults as the borrower will have the expectation of turning to bank for the financial requirements.

Aregawi (2015) examined the causes of non-performing loans and its provision in development bank of Ethiopia. The study sampled 60 firms from both performing and nonperforming clients' and 14 employees using primary data collected through questionnaire and unstructured interview. The findings of the study revealed that demographic characteristics of the clients and employees have significant effect on the repayment of loans. The study concluded that the causes of the non-performing loans are diversion to the other business, marketing problems, inflation condition, lack experts on the business, due to shortage supplies to their business and asymmetric information between the bank and employee. The study recommends that government should extend their Growth and Transformation Plan (GTP) to five years to enable the bank to recognize and reduced the causes of non-performing loans and their provision as a policy on regional level.

However, a number of researchers found significant relationship (i.e,. both positive and negative) between bank specific variables (capital adequacy ratios, loan to deposit ratios, return on assets, total loans and bank size) and macro-economic variables (inflation, lending rate, exchange rate, gross domestic product, unemployment, energy crisis and money in supply) on non-performing loans such as Louzis, Vouldis, and Metaxas, 2010; Joseph, 2011; Sakiru, 2011; Konfi, 2012; Saba, Kauser and Azeem, 2012; Skarica, 2013; Ahmad and Bashir, 2013; Badar and Yasmin, 2013; Tomak, 2013; and Gesu, 2014. This contravene the findings of Djiogap and Ngomsi, 2012; Swamy, 2012; Furhan et al. 2012; Ali and Iva, 2013; and Ranjan \& Chandra, 2013., whose findings were insignificant on non-performing loans in relation to lending rate, inflation, loan to deposits ratio, ROA and GDP.

\section{RESEARCH METHODOLOGY}

The study employed non-survey research design. This is as a result of the fact that, all banks variables are pull out from annual reports and accounts of the sampled money deposit banks. The population of the study involves all the quoted money deposit banks in Nigeria as at 31st December, 2014 which were fifteen (15) in total (NSE, 2014). In other to take appropriate samples we put this checklist for any bank to be eligible as sample of the study, firstly it must be registered in and owned by the Nigerians. Secondly, must have been in operation for at least forty five (45) years from the date of listing in the Nigerian Stock Exchange. Thirdly, it must be an active player on the floor of the Nigerian Stock Exchange as at 31st December, 2014. As a consequence, five banks were disqualified for not fulfilling the above requirements.

The study use two set of variables: dependent, explanatory variables as well as the control variables. The dependent variable is non-performing loan ratio. It is measured in terms of nonperforming loans to gross loan (i.e, total loans).The explanatory and control variables are bank profitability (bank specific variables) and macro-economic determinants which form the independent variables for the study. The study used three techniques for the purpose of data analysis which are descriptive statistic, correlation and multiple regressions (OLS). STATA software version 12 was used.

$$
\begin{aligned}
& \mathrm{NPL}=\mathrm{f}(\mathrm{ROA}, \mathrm{LTD}, \mathrm{CAR}, \mathrm{ALR}, \mathrm{INFL}, \text { and BZ }) \ldots \ldots \ldots \ldots(1) \\
& \mathrm{NPL}=\beta 0+\beta 1(\mathrm{ROA})+\beta 2(\mathrm{LTD})+\beta 3(\mathrm{CAR})+\beta 4(\mathrm{ALR})+\beta 5(\mathrm{INFL})+\beta 6(\mathrm{BZ})+\varepsilon \ldots .
\end{aligned}
$$

Where: $\beta 0 \ldots ., \beta \mathrm{k}$ is the regression model coefficients of the independent variables $\mathrm{NPL}=$ Nonperforming loan ratio of bank. 
ROA $=$ Return on asset ratio of bank.

LTD = Loan to deposit ratio of bank.

CAR = Capital Adequacy ratio of bank.

ALR $=$ Average lending rate of bank.

INFL = Inflation rate of bank.

BZ = Bank Size.

$\varepsilon=$ Random error.

Thus, this model is expressed in line with the one used by Gesu (2014).

\section{RESULTS AND DISCUSSIONS}

This section presents, analyse, interprets and discuss the result obtained from the data generated from annual report and accounts of the sampled deposit money banks for the period of the study. The data was analysed using descriptive statistics, correlation matrix of the dependent and explanatory variables and regression analysis. The descriptive statistics explains the various statistics such as mean and standard deviation and correlation matrix was employ to examine the relationship between the explanatory variables while regression coefficients with the purpose of testing the relationship between variables of the study as well as model estimate presentations. Table 4.1 provides such statistics.

Table 4.1: Descriptive Statistics of the Variables

\begin{tabular}{|c|c|c|c|c|c|}
\hline Variable | & Obs & Mean & Std. Dev. & Min & Max \\
\hline & & & -----1 & -------- & -------ー- \\
\hline Npl | & 50 & .5088449 & .313826 & .021011 & .97174 \\
\hline Roa I & 50 & .0362961 & .0480645 & -.0225464 & .2620823 \\
\hline Car I & 50 & .2659156 & .338092 & .0092536 & 1.511769 \\
\hline Ltd | & 50 & .6643522 & .1638253 & .2039892 & .9751711 \\
\hline Alr | & 50 & .23824 & .0129403 & .2239 & .2574 \\
\hline----- & & & & & ---------- \\
\hline infl| & 50 & .10644 & .0218131 & .0806 & .1372 \\
\hline BZ | & 50 & 9.0213 & .3967162 & 8.033913 & 9.702472 \\
\hline
\end{tabular}

Source: Generated by the Researcher from the Annual Reports and Accounts of the sampled companies using Stata (Version 12).

Table 4.1 reveals that non-performing loans deposit money banks over the period of five years ranged from a minimum of $21 \%$ to a maximum of $97 \%$ and with an average of $51 \%$ and standard deviation values of 0.313826 indicating lack of considerable variation. Other variables which are independent from the table also indicate some level of variability. On the overall bank size has the highest standard deviation with about 0.3967162 followed by capital adequacy ratio with 0.338092 while average lending rate has the lowest standard deviation which account for only 0.0129403 . These indicate that the average lending rate and inflation account for $24 \%$ and $11 \%$ of the non-performing loans of deposit money banks in Nigeria.

In order to examine the level of relationship between the dependent and explanatory variables, correlation matrix is used. Variance Inflation Factor (VIF) test is carried out also to find out whether or not multi-collinearity exists as a result of the relationship between the studied variables. The correlation matrix in Table 2 provides some insights into which of the independent variables are related to the Return on Assets (ROA) (i.e., the dependent variable). 
Table 4.2: Correlation Matrix of the Variables

\begin{tabular}{|c|c|c|c|c|c|c|c|c|}
\hline & I & $\mathrm{Npl}$ & roa & car & 1 td & alr & infl & BZ \\
\hline $\mathrm{Npl}$ & I & 1.0000 & & & & & & \\
\hline Roa & I & -0.3385 & 1.0000 & & & & & \\
\hline Car & | & -0.3751 & 0.7215 & 1.0000 & & & & \\
\hline Ltd & i & 0.4843 & -0.2267 & -0.1272 & 1.0000 & & & \\
\hline Alr & I & -0.0016 & 0.0980 & 0.1867 & 0.1573 & 1.0000 & & \\
\hline Infl & I & 0.0806 & -0.1223 & -0.2539 & -0.0172 & -0.7995 & 1.0000 & \\
\hline BZ & i & 0.4885 & -0.3610 & -0.6891 & 0.0498 & 0.0935 & -0.1037 & 1.0000 \\
\hline
\end{tabular}

Source: Generated by the Researcher from the Annual Reports and Accounts of the sampled companies using Stata (Version 12).

From the above table, the values are in diagonal, all 1.0000 which indicate that every single variable is perfectly correlated with itself. Return on asset (ROA), capital adequacy ratio (CAR) and average lending rate (ALR) are inversely correlated with non-performing loans (NPLs) with correlation coefficient values of $-0.3385,-0.3751$ and -0.0016 which implies that as these variables(ROA, CAR and ALR) increases, non-performing loans (NPLs) decreases. On the other hand, total loan to deposit (LTD) and inflation (INFL) as well as Bank size (BZ) are positively correlated with non-performing loans (NPLs). The positivity nature of the correlations implies that as the rate loan and deposits, inflation and bank size increases, so does the rate nonperforming loans increases with a correlation coefficient value of $0.4843,0.0806$ and 0.4885 respectively. The study advanced further by measuring the validity of multi-collinearity from the correlation matrices, by the use of Tolerance Value (TV) and Variance Inflation Factor (VIF). Table 4.1 presents the results of TV and VIF as the determinants of Non-Performing loans.

\begin{tabular}{rrr}
\multicolumn{3}{c}{ Table 4.3: Multi-collinearity Test } \\
Variable | & VIF & $1 / \mathrm{VIF}$ \\
- car | & 4.80 & 0.208436 \\
Infl & 3.25 & 0.307541 \\
Alr | & 2.96 & 0.337982 \\
BZ | & 2.55 & 0.391930 \\
Roa | & 2.46 & 0.405955 \\
Ltd | & 1.13 & 0.886496 \\
---------+-------------- \\
Mean VIF |
\end{tabular}

Source: Generated by the Researcher from the Annual Reports and Accounts of the sampled companies using Stata (Version 12).

Table 4.3, shows that TV ranges from 0.208436 to 0.886496 which proposes non multicollinearity feature. Multi-collinearity feature subsists when the value of TV is less than 0.2 (Sabari, 2012 as cited by Kurawa and Kabara, 2014). VIF is simply the reciprocal of TV ranges from 4.80 to 1.13 which shows absence of Multi-collinearity, with the average VIF of 2.86 for all the variables. VIF displays Multi-collinearity where the value surpasses 10 (Sabari, 2012 as cited by Kurawa and Kabara, 2014). 
Table 4.4: Regression Result

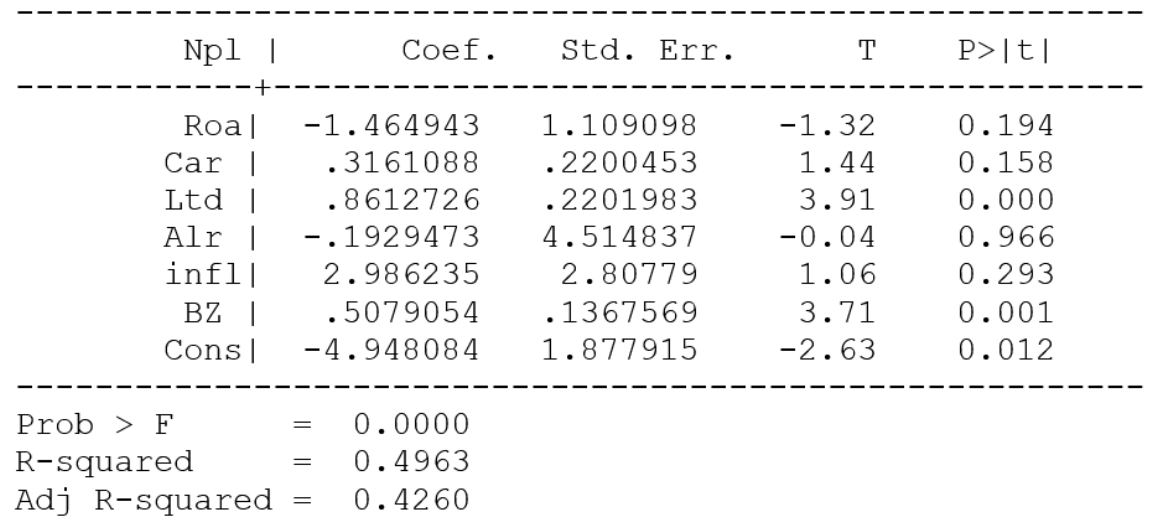

\section{Source: Generated by the Researcher from the Annual Reports and Accounts of the sampled} companies using Stata (Version 12).

Table 4.4 presents the regression results of the dependent variable (NPLs) and independents as well as explanatory variables (ROA, CAR, LTD, ALR, INFL and BZ). The coefficient of "Rsquared" shows $49.63 \%$ which indicate that the variables used in the model accounts for about $49.63 \%$ variation on NPLs as the dependent variable, whereas the remaining of the variation accounts for the outcome of other variables which were not considered by this model. However, the whole probability is significant at $1 \%$ level of significance. As such, the model of the equation can be inscribed as: NPLs $=-4.948084-1.464943 \beta 1+.3161088 \beta 2+.8612726 \beta 3$ $-.1929473 \beta 4+2.986235 \beta 5+.5079054+\varepsilon$

In assessing the model of the regression equation, the results shows that, the relationship between NPLs and ROA is negative while CAR and INFL is positive, but all insignificant, which can be justified with " $t$ " values of $-1.32,1.44$ and 1.06 and $P>|t| 0.194,0.158$, and 0.293 respectively with the following coefficients result $-1.464943,0.3161088$ and 2.986235 , which means deterioration of profitability ratio measured by ROA leads to riskier activities of banks and then raise the level of NPLs. Hence, ROA represents efficiency in asset utilization, poor utilization of assets indicates higher NPLs for the banks which is in line the findings of Boudriga et a., 2009; and Selma \& Jouini, 2013 and conflict with that of Gesu, 2014; Ahmed \& Bashir 2013; and Makri, Tsagkanos and Bellas, 2014 whose findings were positive significant relationships between ROA and NPLs.

As to that of CAR means that the degree of banks solvency, ability to absorb risk, to protect depositors and to encourage stability as well as efficiency of financial systems has no significant relationship on NPLs. This is consistent with the findings of Djiogap and Ngomsi, 2012; Swamy, 2012; Skarica, 2013 and Ali and Iva, 2013., which on the on the hand contravene the findings of Saba, Kauser and Azeem, 2012; Konfi, 2012; Furham et al., 2012; Tomak, 2013 and Badar and Yasmin, 2013.

So also the relationship between ALR and NPLs is insignificant and negative, which is can be justified with negative " $t$ " value of -0.04 and $P>|t| 0.966$ which also has a negative coefficient of -0.1929473, this implies that, lending rate affect performing assets in banks but does not increase the cost of loans charged on the borrowers which is consistent with the findings of Tomak, 2013 on interest rate. These results contravene the views of louzis, Vouldis and Metaxas, (2010); Sakiru, (2012); and Joseph, (2011).

LTD has a positive and statistically significant relationship with NPLs. Justifiable with " $t$ " value of 3.91 and $P>|t| 0.000$ as well as a positive coefficient of 0.8612726 , meaning that bank liquidity has a significant relationship with NPLs, that is, increase in LTD by 1 unit leads to 
same increase in NPLs, as banks used deposits collected from the customers for loans as the normal banking business. The result is consistent with the findings of swammy (2012); and Gesu (2014) and conflict with that of Ranjan and Chandra, (2013) who maintained that loan to deposits ration has a negative and insignificant impact on non-performing loans. Finally, the result of bank size indicate positive with a significant relationship at $1 \%$ level of significance on non-performing loans of the sampled money deposit banks in Nigeria with a coefficient value of 0.5079054 and $P>|t| 0.001$ standard deviation of 0.1367569 with a " $t$ " value of 3.71, which indicate that the size of the bank has something do with it the rate of non-performing loans which is consistent to that of swamy, (2012).

\section{CONCLUSION AND RECOMMENDATIONS}

The paper examines the impact of non-performing loans on bank specific and macro-economic variables in the Nigerian deposit money banks. From the result of the findings in the study, it can be inferred that non-performing loans does not decreases bank performance as; There is no statistically significant relationship between NPLs and ROA this because ROA represents efficiency in asset utilization, poor utilization of assets indicates higher NPLs for the banks, there is no significant causal relationship between NPLs and CAR as banks solvency, ability to absorb risk and to encourage financial stability as well as efficiency has nothing do with NPLs as shown by the regression results and also there is statistically positive insignificant causal relationship between NPLs and INFL this is because when other things remain constant, inflation has on effect on NPLs in the Nigerian money deposit banks as well as insignificant relationship between ALR and NPLs which is because lending rate affect performing assets in banks but does not increase the cost of loans charged on the borrowers.

The study also found positive significant relationship between LTD and NPLs; this is because customer's deposits are mostly used for loan which variably turns up to NPLs. There is also significant relationship between Bank size and NPLs as revealed by the regression result, thus, the higher the deposit and bank size, the higher the loans, and NPLs.

Based on the findings, the paper recommends for a sound management of non-performing loan to achieve economic growth in Nigeria and CBN for policy purposes should frequently assess the lending habit of deposit money banks in Nigeria. It is also suggested that the supervisory authorities should take part actively in capacity building to enhance supervisory and regulatory functions effectively. Finally, strengthening securities market will have a positive impact on the general improvement of the banking institutes' thereby increasing effectiveness in the financial sector.

\section{References}

Ahmed, F. and Bashir. K. (2013). Explanatory Power of Macroeconomic Variables as Determinants of NonPerforming Loans: Evidence Form Pakistan, World Applied Sciences Journal Vol, 22 (2). Pp; 243-255.

Akpan, U. A. (2013). Relevance of the Asset Management Corporation of Nigeria (AMCON) to the Non- Performing Loans of Deposit Money Banks. InternationalJournal of Economics, Business and Finance Vol. 1(8), PP: 249 -261. Available online at http://ijebf.com/ 249.

Ali S. and Iva S. (2013). Impact of Bank Specific Variables on the Nonperforming loans ratio in Albanian Banking System, Journal of Finance and Accounting: Vol. (4), Pp; 34-56.

Ailemen, O. I. (2012). Bank Capitalization and Performance in Nigerian Banking Industry (1986-2006): Empirical Evidence, European Journal of Accounting, Auditing and Finance Research Vol 1(4), pp.12-32, (www.eajournals.org). 
Aregawi, H. T. (2015). Causes of Nonperforming Loans and its Provision in the Case of Development Bank of Ethiopia - Dessie Branch. Research Journal of Finance and Accounting. Vol.6 (17).

Asset Management Corporation of Nigeria (2013). Management Presentation (available at www.amcon.com.ng)

Basel Committee on Banking Supervision (2001). Risk Management Practices andRegulatory Capital: CrossSectional Comparison (available at www.bis.org)

Badar, M. \& Yasmin, A. (2013). Impact of Macroeconomic Forces on Nonperforming Loans: an Empirical Study of Commercial Banks in Pakistan; Journal of Transactions onBusiness and Economics: Vol. 10(1), pp23-45.

Boudriga, A., Boulila, T. N. and Jellouli, S. (2009). Bank Specific, Business and Institutional, Environment Determinants of Nonperforming Loans: Evidence from MENA Countries, Journal of Financial Economic Policy. Vol. 1 (4), Pp. 286-318

Central Bank of Nigeria (2015). Banking Supervision Annual Report (Available at www.cbn.gov.ng)

Central Bank of Nigeria (2010). Prudential Guidelines for Deposit Money Banks in Nigeria (available at www.cbn.gov.ng)

Djiogap, F. and Ngomsi, A. (2012). Determinants of Bank Long-Term Lending Behavior in the Central African Economic and Monetary Community (CEMAC), Review of Economics \&Finance; 1923-7529-2012-02-107-08,

Farhan, M., Sattar, A. C., Hussain, A. and Khalil, F. (2012). Economic Determinants ofNon-Performing Loans: Perception of Pakistani Bankers European; Journal of Business and Management, Vol4, No.19,

Federal Government of Nigeria (2011). Nigeria Deposit Insurance Corporation Report 2011: Financial Conditions of Insured Deposit Money Banks in 2011, NDIC 2011 AnnualReport \& Statement of Accounts, pp.133-134.

Felix, A. T. \& Cloudine, T.N. (2008). Bank Performance and credit Risk Management; published thesis (MSc), University of Skovde.

Haneef, S., Riasz T., Razman, M., Ali, M. R., Muhammed, H. I. \& Karim, Y. (2012). Impactof Risk Management on Nonperforming Loans and Profitability of Banking Sector of Pakistan; International Journal of Business and Social Science Vol. 3 (7).

Gesu, G. (2014). Determinants of Nonperforming Loans: Empirical Study in Case ofCommercial Banks in Ethiopia. A Published Msc Thesis, Jimma University. IMF, Annual report (2005).

Joseph, C. N. (2011). The Effects of Interest Rate Spread on the Level of Non-Performing Assets: A Case of Commercial Banks in Kenya. International Journal of Business and Public Management (ISSN: 2223-6244) Vol. 1(1): 58-65.

Kargi, H. S. (2011). Credit Risk and the Performance of Nigerian Banks, Ahmadu Bello University, Zaria.

Konfi, S. (2012): Determining Causes and Impact of Nonperforming Loans on the Operations of Microfinance Institutions: A Case of Sinapi Aba Trust in Ghana.Published thesis (MBA), Kwame Nkrumah University.

Korankye, A. A. (2014). Causes and Control of Loan Default/Delinquency in Microfinance Institutions in Ghana. American International Journal of Contemporary Research Vol. 4 (12), Pp; 36-47.

Kurawa, J. M and Kabara, A. S. (2014). Impact of Corporate Governance on Voluntary

Disclosure by Firms in the Downstream Sector of the Nigerian Petroleum Industry. Proceedings of World Business Research Conference. Novotel World Trade Centre, Dubai.

Leroy, M. R. and Vanhoos, D. D. (2006). Modern Money and Banking, 3rd edition.

Loizis, P. D., Vouldis, T. A. and Metaxas, V. (2010). The Determinants of Non- Performing Mortgage, Business and Consumer Loans in Greece: Athens, Published thesis (MSc), Athens University.

Macdonald, S. S. (2006). Management of Banking; 6th edition.

Makri, V., Tsagkanos, A. and Bellas, A. (2014). Determinants of Nonperforming Loans: The Case of Eurozone. Panoeconomicus, Volume 2, Pp. 193-206.

Mileris, R. (2012). Macroeconomic Determinants of Loan Portfolio Credit Risk in Banks, InzinerineekonomikaJournal of Engineering Economics, 23(5), 496-504. 
El-Maude, J.G., Abdul-Rehman, A. \& Ibrahim, M. (2017). Determinants of Non-Performing Loans in Nigeria's Deposit Money Banks. Archives of Business Research, 5(1), 74-88.

Ngoc, V. T., Trien, L. V. and Diep, H. (2014). Macro Determinants on Non-performing Loans and Stress Testing of Vietnamese Commercial Banks' Credit Risk, VNU Journal of Science: Economics and Business, Vol. 30 (5E), Pp; 116.

Nigerian Stock Exchange (2014).Annual Report \& Accounts, (Available at www.nse.gov.ng)

Nkurrunah, N. (2014). Factors Affecting Non-Performing Loans: A Case Study of CommercialBank of Africa - CBA (Kenya), Published MBA Project by United States International University- Africa.

Ranjan, R. and Chandra, D. S. (2003). Non-Performing Loans and Terms of Credit of Public Sector Banks in India: An Empirical Assessment; India, Reserve Bank of India Occasional Papers Vol. 24(3).

Rawlin, R., Shwetha, M., Sharan, M. and Pradeep, B. L. (2012). Modeling the NPA of Midsized Indian Nationalized Bank as Function of Advances; European Journal of Business and Management, Vol 4(5).

Saba. I., Kouser, R. and Azeem, M. (2012). Determinants of nonperforming Loans: Case of US Banking Sector. International Journal of Banking and Finance; No. 44 Pp 479-88.

Sabari, M. H. (2012). Risk and Uncertainties as Determinants of Size of Recapitalised Banks in Nigeria. ICAN Journal of Accounting and Finance (IJAF). Vol. 1 No. 4 pp. 87-104.

Sakiru, A. S., Sulaiman, W., Yussof, W., Muamalat, K., and Dahalance, J. (2011). ARDL Approach to the Determinants of Nonperforming Loans in Islamic Banking System in Malaysia; Journal of Business and Management Review Vol. $1(2)$.

Selma.M. Ahlem and Jouini, F. (2013). Micro and Micro determinants of Nonperforming; Tunisia, International Journal of Economics and Financial Issues. Vol.3 (4), pp; 852-860,

Skarica, B. (2013). Determinants of Non-Performing Loans in Central and Eastern European Countries: Working Paper. No 13-07.

Swamy, V. (2012). Impact of Macroeconomic and Endogenous Factors on Nonperforming Bank Assets: International Journal of Banking and Finance, Vol. 9.

Thomas, L. B. (2006). Money Banking and Financial Markets.pp 211.

Tomak, S. (2013). Determinants of Commercial Banks 'lending Behavior: Evidence from Turkey: Journal of Empirical Research, 3(8), Pp: 933-943.

Tseganesh, T. (2012). Determinants of Banks Liquidity and Their Impact on Financial Performance: Published thesis (MSc), University Addis Ababa, Ethiopia.

Zewdu, S. (2010). Impact of reducing loan by Ethiopian banks on their own performance; published thesis (MSc), University of South Africa. 